\title{
First results of the study of obligatorily myrmecophilous aphids (Hemiptera: Sternorrhyncha: Aphididae) of south-eastern Belarus
}

\author{
Artsiom M. Ostrovsky \\ Gomel State Medical University, ul. Lange 5, Gomel, 246000 Republic of Belarus \\ arti301989@mail.ru
}

Received: 23.02.2021

Revised: 22.03.2021

Accepted: 26.03.2021

Published online: 30.04 .2021

DOI: $10.23859 /$ estr-210223

UDC 595.752.2 (476.2)

Translated by S.V. Nikolaeva
Abstract. Five species of obligatorily myrmecophilous aphids of two subfamilies were found in south-eastern Belarus during studies conducted in 2018-2020. The species Stomaphis quercus (L., 1758) is new for the Belarus aphid fauna. The vast majority of aphids in this group are holocyclic dendrophilous species. Only one species of herbophilous aphid Paracletus cimiciformis von Heyden, 1837 in Belarus is represented by an anholocyclic clone.

Keywords: species diversity, biotope allocation, distribution, synonymy.

To cite this article. Ostrovsky, A.M., 2021. First results of the study of obligatorily myrmecophilous aphids (Hemiptera: Sternorrhyncha: Aphididae) of south-eastern Belarus. Ecosystem Transformation 4 (2), 41-47. https://doi.org/10.23859/estr-210223

\section{Introduction}

Aphids (Hemiptera: Aphididae) are one of the most numerous and widespread groups of hemipterans and play an important role in terrestrial ecosystems. They are food objects for many invertebrate species (Aleeva and Babushkina, 1977; Barannik, 1973; Davidyan, 2007; Filatova, 1970; Krotova, 1991, 1992; Nixon, 1951; Panfilova, 1972; Tobias and Kiriyak, 1986) and are the main supplier of carbohydrate food for ants (Dlussky, 1967; Hölldobler and Wilson, 1990; Mordvilko, 1901, 1936).

By the nature of their relationship with ants, aphids are divided into myrmecophilous (associated with ants) and non-myrmecophilous (not associated). Myrmecophilous aphids, in turn, are divided into obligate and optional. The former are extremely rarely found without ants, the latter can be found with or without ants. Currently, there is evidence of the existence of a wide range of transitional forms of interactions between ants and aphids from mutualism to exploitation (Offenberg, 2001; Pälsson, 2002). In ad- dition, there is evidence that the prosperity of myrmecophilous aphids depends on the species of the symbiont partner (Addicott, 1978; Bristow, 1984). There is reason to believe that this is due to the organization of honeydew collection by different ants (Novgorodova, 2005). At the same time, the degree of influence of various members of multispecies ant communities on the survival rate of myrmecophilous aphids is still virtually unexplored. This work presents the first results of the study of obligatorily myrmecophilous aphids in the south-east of Belarus.

\section{Materials and methods}

The material for the study was from the author's own collecting in the period 2018-2020, which were carried out manually from the bark and shoots of trees, as well as from anthills in forest and forest-steppe biocenoses in the southeast of Belarus. The collected aphids were fixed in $75 \%$ ethyl alcohol with a small addition of glycerin, which insures against accidental drying out and reduces the fragility of insects. The collect- 
ed material was identified according to the taxonomic keys of Shaposhnikov (1964), Heie (1980, 1982, 1986, 1992, 1994, 1995), Blackman and Eastop (2006a, 2006b) by morphometric examination of prepared microscopic specimens of aphids under laboratory conditions. Synonymy and taxonomy follows Remaudière and Remaudière (1997). A total of 321 specimens were examined.

\section{Results}

Studies have shown that the majority of aphids living in the south-east of Belarus belong to non-myrmecophilous and optionally myrmecophilous species. The group of obligate myrmecophiles is very small and includes 5 species in our collections. Representatives of the genus Stomaphis Walker, 1870 were found on the surface and in cracks in the bark of an pedunculate oak (Quercus robur L.) inhabited by the ants Lasius fuliginosus (Latreille, 1798) and L. brunneus (Latreille, 1798). Three more species were found in ant nests of Formica rufa L., 1761, as well as in the anthills of $L$. flavus (Fabricius, 1782) and Tetramorium caespitum (L., 1758). Below are data on their distribution and lifestyle.

\section{SUPERFAMILY APHIDOIDEA LATREILLE, 1802 FAMILY APHIDIDAE LATREILLE, 1802 Subfamily Eriosomatinae Baker, 1920 Tribe Eriosomatini Baker, 1920}

\section{Genus Tetraneura Hartig, 1841}

Synonyms: Amycla Koch, 1857; Byrsocrypta Haliday, 1838; Brysocrypta Westwood, 1840; Dryopela Kirkaldy, 1904; Endeis Koch, 1857 nec Philippi, 1847; Tetranema Derbes, 1869; Tetrenema Derbes, 1869; Tetranevra Agassiz, 1846.

Large, originally Palaearctic, genus with 38 species and subspecies in the world fauna, most of which live in East Asia. Consists of three subgenera: Tetraneura sensu stricto (24 species), Indotetraneura Chakrabarti and Maity, 1978 (5 species), Tetraneurella Hille Ris Lambers, 1970 (9 species and subspecies). Trophically related to elm (Ulmaceae) and cereals (Poaceae). Some species migrate between them, some live monoeciously. Small stalked galls are formed on the leaves of elms; on cereals they live on the roots.

\section{Tetraneura (s. str.) ulmi (L., 1758)}

Synonyms: Amycla fuscifrons C.L. Koch, 1857; Aphis gallarum J.F. Gmelin, 1790; A. gallarum-ulmi Goeze, 1778; A. gallarumulmi De Geer, 1773; A. gallarum ulmi De Geer, 1773; A. radicum Boyer de Fonscolombe, 1841; A. ulmi L., 1758; Byrsocrypta gallarum (J.F. Gmelin, 1790); B. personata Börner, 1950; B. saccharata Schouteden, 1907; Colopha ulmisacculi (Patch, 1910); Cryptosiphum gallarum (J.F. Gmelin,
1790); Dryopeia rosea (C.L. Koch, 1857); Endeis bella C.L. Koch, 1857; E. rorea C.L. Koch, 1857; E. rosea C.L. Koch, 1857; Pemphigus fuscifrons (C.L. Koch, 1857); P. f. var. saccarata Del Guercio, 1895; P. graminis Schouteden, 1906; P. zeae-maydis Nevsky, 1929; P. zeaemaydis (Dufour, 1824); P. zeamaidis Macchiati, 1883; Tetraneura boyeri Passerini, 1856; T. b. var. saccharata Del Guercio, 1900; T. gallarum (J.F. Gmelin, 1790); T. rosea (C.L. Koch, 1857); T. saccharata Schouteden, 1907; T. theobaldi Zwölfer, 1957; T. ulmi f. personata (Börner, 1950); T. ulmi-sacculi Nevsky, 1929; T. ulmifoliae A.C. Baker, 1920; T. ulmigallarum Haliday, 1838; T. ulmisacculi Patch, 1910; T. zeaemaydis Nevsky, 1929; T. zeamaydis Zwölfer, 1957; Trama radicis (Boyer de Fonscolombe, 1841).

T. ulmi - transpalaearctic polyzonal mesoxerophilic species (Kadyrbekov, 2017). Found throughout the Palaearctic, introduced to North America. Inhabits the European part of Russia (north to St. Petersburg), the Caucasus, Central Asia, Siberia, Primorye and Ukraine (Mamontova, 1973).

A heteroecious species living in small galls that form on the upper side of elm leaves migrates in summer to the roots of various grasses, which serve as a secondary host for the species. The founders emerge from the eggs that have overwintered on the bark of the elm trunks during the budding period and move on to developing leaves. Resulting from their activity, a stalked, closed green, later reddening, gall ranging in size from a pea to a hazelnut is formed on the leaf blade between the veins. Galls are thick-walled and smooth. On one leaf there can be from 1 to 40 such galls, sometimes they cover the entire leaf blade and most of the leaves on the tree. One founder hatches up to 40 larvae of winged migrants, which emerge from the cracked gall at the beginning or end of June and migrate to the roots of cultivated and wild grasses within 2-3 weeks. After migration to grasses, T. ulmi behaves like an obligate myrmecophile: it is invariably visited by various ants, is often found in their nests, and reproduces asexually (Blackman and Eastop, 2014). In October, winged individuals appear, they fly to elms and here in the cracks of the trunk bark they produce larvae (males and amphigonous females). The full life cycle of the species ends with the laying of overwintering eggs. Additionally, unmated wingless individuals regularly overwinter on the roots of wild-growing cereals, that is, along with the full-cycle development, there is also an incomplete cycle development of the species (Mamontova, 1973).

The species tends more towards steppe habitats. In southeastern Belarus, seven individuals of $T$. ulmi (Fig. 1) were found in a Lasius flavus nest under a cover on the ground near the village of Krasnoe Znamya (Buda-Koshelevo District of the Gomel Region) (April 15, 2018). 

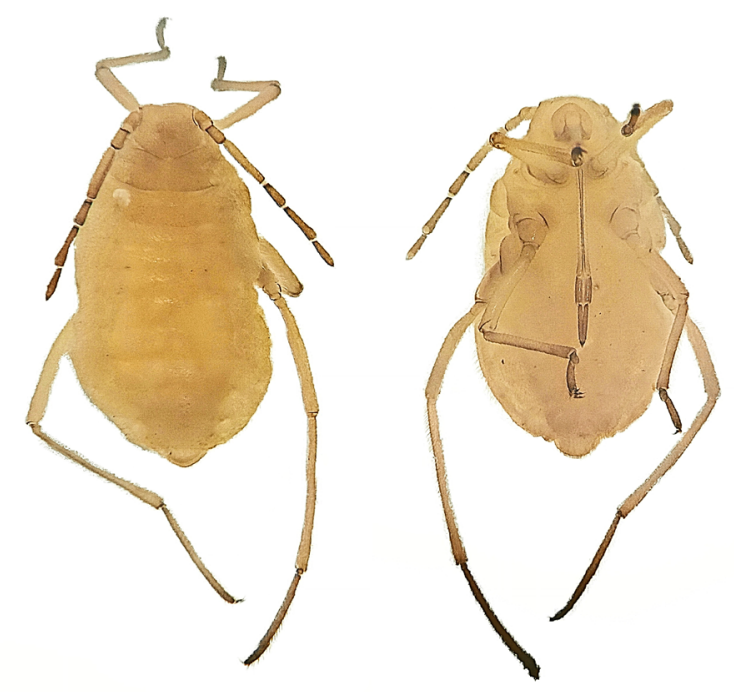

Fig. 1. Tetraneura (s. str.) ulmi (L., 1758).

\section{Tribe Fordini Baker, 1920}

\section{Genus Paracletus von Heyden, 1837}

Synonyms: Fordona Mordvilko, 1935; Hemitrama Mordvilko, 1921; Paracletius Amyot, 1847.

A small Palaearctic genus with 7 species and subspecies in the world fauna. Trophically related to pistachio (Pistacia), on which it forms galls. Some species migrate to the roots of Poaceae, while others live on the roots of cereals in an incomplete cycle.

\section{Paracletus cimiciformis von Heyden, 1837}

Synonyms: Forda harukawai Tanaka, 1957; F. rotunda Theobald, 1914; F. skorkini Mordvilko, 1935; Fordona italica Mordvilko, 1935; Pemphigus derbesi Lichtenstein, 1880; P. pallidoides Lichtenstein, 1880; Paracletius cimiciformis (von Heyden, 1837); Paracletus pallidus Derbes, 1869; P. portschinskyi Mordvilko, 1921; P. portshinskyi Mordvilko, 1921.

$P$. cimiciformis - rare, sporadically occurring, transpalaearctic polyzonal meso-xerophilic species (Kadyrbekov, 2017). Distributed in Western Europe, North Africa, Asia Minor and Western Asia. Inhabits the European part of Russia, the Caucasus and the Urals, Siberia (up to the Ob River), Central Asia and Ukraine (Mamontova, 1973).

In southern Europe, the main host plant of $P$. cimiciformis is the turpentine tree (Pistacia terebinthus L., 1753), in Iran, $P$. khinjuk Stocks, 1852, from which aphids migrate to secondary hosts (various types of cereals). For most of the year, wingless females produce parthenogenetic offspring, but at the end of summer, winged males and females appear, which migrate to the main host plant, where they mate and lay overwintering eggs. In the spring, wingless females appear, form galls on the leaves, where they live and reproduce asexually. At the end of summer, winged females develop, colonizing the roots of cereals. Some of these aphids overwinter in ant nests and emerge in the spring to repopulate the roots of the grasses. The whole cycle takes two years. In the temperate zone of the European continent, the cycle is incomplete, only on cereals: wheat, barley and wild species (wheatgrass, etc.). It occurs in a community with the ants Tetramorium caespitum and Plagiolepis pygmaea (Latreille, 1798), in the nests of which the aphids overwinter.

In our conditions, aphids have two morphologically different, but genetically identical forms. One of these forms, characterized by a rounded green body and five-segmented antennae, feeds on the sap of the host plant, producing honeydew, which ants willingly eat; in this case, the ants actually shepherd the aphids, stimulating honeydew production. The other form, with its characteristic six-segmented antennae and a flattened yellowish body (Fig. 2), releases three chemicals that are similar in composition and odor to the pheromones produced by ant larvae. When the ant approaches, these aphids freeze and in this form are transferred to the brood chambers of the anthill. Here they begin to actively hunt ant larvae, piercing their body with stylets and sucking out hemolymph. In the anthill they hibernate, and in the spring, they come to the surface of the ground and produce aphids with a rounded body, which feed on roots and reproduce asexually. Both rounded and flattened morphs can reproduce parthenogenetically, producing offspring of any shape. However, it is still unclear what factors influence the formation of one or another morph of P. cimiciformis (Kadyrbekov, 2017; Mamontova, 1973; Mróz and Depa, 2012).

In the southeast of Belarus, predatory morphs of this species were found in a T. caespitum anthill: the western outskirts of Gomel, Makeevskoe forestry, a power line clearing in a mixed forest (April 30, 2020)

\section{Subfamily Lachninae Herrich-Schaeffer, 1854 Tribe Lachnini Herrich-Shaeffer, 1854}

\section{Genus Lachnus Burmeister, 1835}

Synonyms: Dryaphis Kirkaldy, 1904; Dryaphis Amyot, 1847; Dryobius Koch, 1855 nec Le Conte, 1850; Lachuns Passerini, 1863; Lachunus Williams,
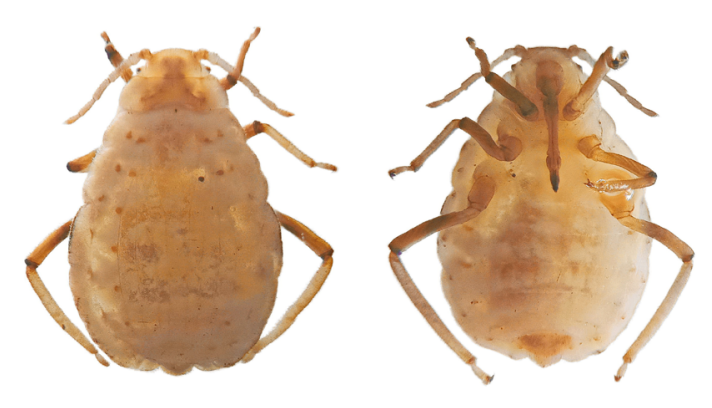

Fig. 2. Paracletus cimiciformis von Heyden, 1837. 
1891; Laehnus Mordvilko, 1914; Laenus Mordvilko, 1914; Pterochlorus Passerini, 1860; Pteroclorus Rondani, 1848; Pteroechlorus Mordvilko, 1914; Ptevochlorus Mordvilko, 1914; Schizodryobius van der Goot, 1913; Sublachnobius Heinze, 1962; Taeniolachnus Amyot, 1847.

Holarctic genus with 28 extant species and subspecies in the world fauna, most of which live in East Asia. Trophically related to beech flowers (Fagaceae). The known species are monoecious, narrow oligophages or monophages.

\section{Lachnus roboris (L., 1758)}

Synonyms: Aphis fasciatus (Burmeister, 1835); A. ilicicola Boisduval, 1867; A. longipes Dufour, 1833; Cinara roboris (L., 1758); Dryaphis cerricola Del Guercio, 1909; D. ilicina Del Guercio, 1909; D. Iongipes (Dufour, 1833); D. roboris (L., 1758); D. roboris subsp. nigra Del Guercio, 1909; Dryobius croaticus C.L. Koch, 1855; D. roboris (L., 1758); Lachniella fasciata (Burmeister, 1835); Lachnus boerneri Pašek, 1953; L. börneri Pašek, 1953; L. castaneae Hille Ris Lambers, 1967; L. cerricola (Del Guercio, 1909); L. croaticus (C.L. Koch, 1855); L. fasciatus Burmeister, 1835; L. ilicicola (Boisduval, 1867); L. lepineyi (Mimeur, 1934); L. longipes (Dufour, 1833); L. roboris subsp. roborus (L., 1758); L. r. subsp. sessilis Börner, 1940; L. sachtlebeni Börner, 1952; L. sessilis Börner, 1940; Lygaeus hyalinatus Fabricius, 1794; Pterochlorus lepineyi Mimeur, 1934; P. longipes (Dufour, 1833); P. roboris (L., 1758); Pteroclorus roboris (L., 1758); Schizodryobius boerneri (Pašek, 1953); Sch. börneri (Pašek, 1953); Schizolachnus fasciatus (Burmeister, 1835); Taeniolachnus fasciatus (Burmeister, 1835).

L. roboris - transpalaearctic nemoral species (Kadyrbekov, 2017). Found in Eurasia and North Africa, introduced to North America. Inhabits the European part of Russia, Eastern Siberia, the Caucasus and the Far East, Western Kazakhstan, Hungary, Turkey, Lebanon, Latvia, Moldova and Ukraine (Mamontova, 1973; Kadyrbekov, 2017).

Monoecious, non-migratory species, narrow oligophage, sporadically found in floodplain oak forests and settlements. Aphids live on the bark of one-threeyear-old shoots of various types of oak, sometimes on the stalks and plumes of acorns in scattered colonies. The founders hatch in April, with the beginning of budding on the trees. An adult female hatches up to 35 larvae, up to eight specimens per day and dies 8-14 days after the birth of the first larva. In summer, colonies are always in symbiosis with Formica rufa ants. Winged individuals already appear in the second generation and are common in colonies; the amphigonous generation occurs in September-October, sometimes even in August. There are always fewer males than females (in a ratio of approximately $1: 10)$. One male mates with several females, after

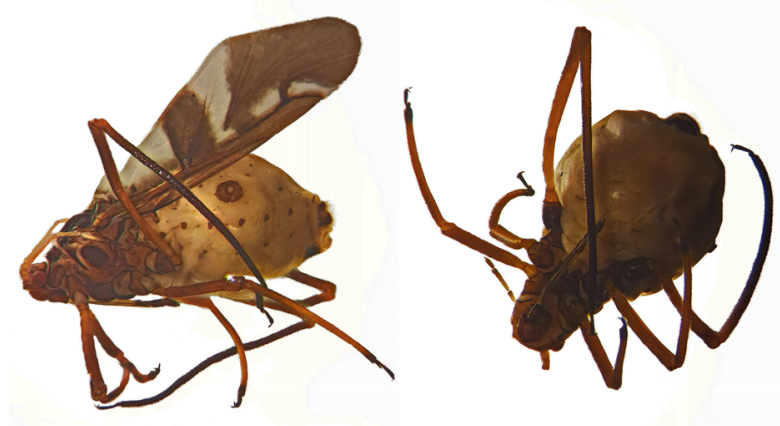

Fig. 3. Lachnus roboris (L., 1758).

which the latter lay elongated shiny black eggs on the bark of the branches in a continuous layer, sometimes covering the entire branch; such a clutch can contain up to 1200 eggs. Aphids can cause great harm to oak trees, especially young ones, directly by sucking the sap and indirectly, contributing to the development of transverse oak canker (Mamontova, 1973).

In the south-east of Belarus, a small colony of L. roboris (Fig. 3) was found on young shoots of pedunculate oak in a community with $F$. rufa ants in a mixed forest on the banks of the Iput River near the village of Larishchevo, Dobrush district, Gomel region (August 14, 2020).

\section{Genus Stomaphis Walker, 1870}

Synonyms: Macrhynchus Haupt, 1913; Neostomaphis Takahashi, 1960; Rhynchocles Altum, 1882.

Palaearctic genus with 37 extant species and subspecies in the world fauna, most of which live in East Asia. The genus includes two subgenera: Stomaphis sensu stricto (30 species and subspecies) and Parastomaphis Pašek, 1953 (7 species and subspecies). Trophically related to various deciduous trees.

\section{Stomaphis quercus (L., 1758)}

Synonyms: Aphis fusca Geoffroy, 1762; A. quercus Fourcroy, 1785; A. quercus L., 1758; Lachnus quercus (L., 1758); L. qvercus Kaltenbach, 1843; Macrhynchus pini Haupt, 1913; Phylloxera longirostris Boyer de Fonscolombe, 1841; Rhynchocles longirostris Altum, 1882; Stomaphis betulae Mamontova, 1969; S. macrorhyncha Cholodkovsky, 1894; S. querceus Harrington, 1985; S. quercuus Tóth, 1933.

$S$. quercus - West Palaearctic polyzonal species (Kadyrbekov, 2017). It is found in Western Europe, Latvia, Moldova, Ukraine (sporadically from Polesie to the steppe zone), Russia (to Western Siberia), Central Asia and Kazakhstan (north, east) (Kadyrbekov, 2017; Mamontova, 1973). It is recorded for the first time for Belarus.

A monoecious, non-migratory species, narrow oligophage. Lives openly on the trunk and crevices of the bark in symbiosis with the ants Lasius fuliginosus 
(Depa et al., 2012). The amphigonous generation appears in September-October. Males molt only twice, after which they mate with females, which lay overwintering eggs. Subsequently, these eggs are carried by ants to nests underground, where they overwinter (Pontin, 1960). From time to time, the ants lick the eggs, probably to kill hyphae and fungal spores. If the ants are removed, the eggs dry out or become moldy very quickly, and the number of founding larvae emerging from the eggs sharply decreases (Mamontova, 1973).

In the south-east of Belarus, the first colonies of S. quercus (Fig. 4) were found in the autumn of 2020 in a forest to the south-east of Gomel. The material (40 imago, 12 exuviae, and 78 eggs) was collected by the author on October 11, 2020, from the surface and cracks in the bark at a height of $1.5-2.0 \mathrm{~m}$ from the base a the pedunculate oak trunk in a deciduous forest on Korenevskoe forestry land.

\section{Stomaphis wojciechowskii Depa, 2012}

S. wojciechowskii - West Palaearctic polyzonal species. Currently known from Poland, Hungary, Romania, Slovakia, Slovenia, and the UK (Hodgson et al., 2019). Relatively recently discovered in Belarus (Ostrovsky, 2021). A monoecious, non-migratory species, narrow oligophage. Leads a hidden way of life in deep cracks in the bark in symbiosis with ants Lasius brunneus on different species of oak (Q. cerris L., Q. petraea (Mattuschka) Liebl., Q. robur L.), smallleaved lime (Tilia cordata Miller), black alder (Alnus glutinosa (L.) Gaertner), white willow (Salix alba L.) and walnut (Juglans regia L.) (Depa et al., 2012; Hodgson et al., 2019).

It is now known from the life cycle of $S$. wojciechowskii that the first larvae emerge from overwintered eggs in early spring and, apparently, develop rather slowly, since mature founding females on the pedunculate oak appear only in June (Depa and Mróz, 2012). They produce live offspring (without fertiliza-
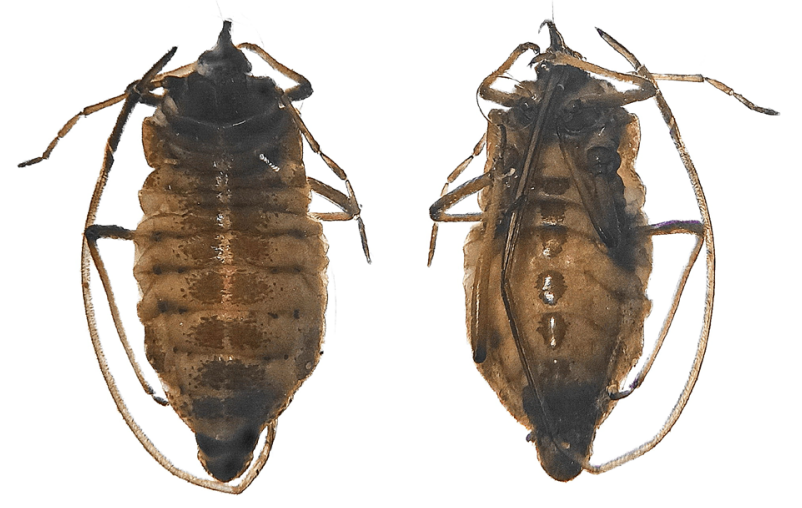

Fig. 4. Stomaphis quercus (L., 1758).

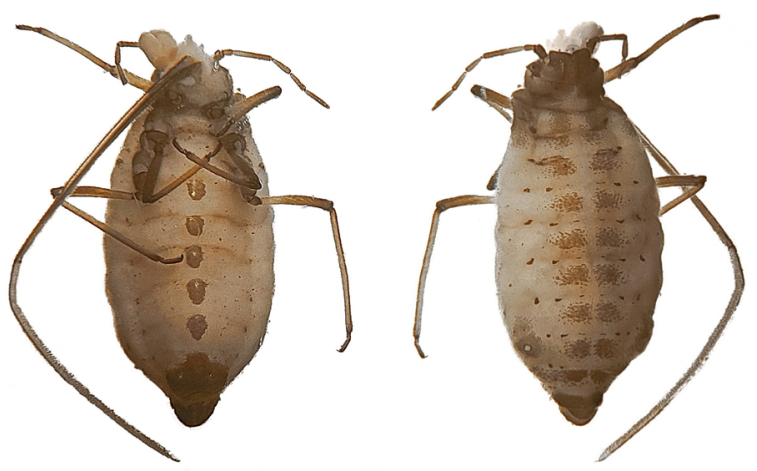

Fig. 5. Stomaphis wojciechowskii Depa, 2012.

tion). Grown wingless females reproduce in the same way. In parallel, winged individuals appear, which are found throughout the summer. Sexual forms, i.e., oviparous females and small wingless males, appear in autumn. The eggs remain for the winter, and the next spring their life cycle repeats again.

The first colonies of S. wojciechowskii (Fig. 5) in Belarus were discovered in October 2019-2020 in the vicinity of Gomel (Ostrovsky, 2021). We found large yellow eggs and wingless females in the ant tunnels of $L$. brunneus under the bark of an pedunculate oak in October (October 20, 2019, October 27, 2019, and October 11, 2020).

\section{Conclusions}

Thus, as a result of the studies carried out on the territory of the southeast of Belarus, five species of obligatorily myrmecophilous aphids were identified, among which Stomaphis quercus (L., 1758) is new to the aphidofauna of the republic. The overwhelming majority of aphids in this group are holocyclic dendrophilous species. Only one species of herbophilous root aphids, $P$. cimiciformis, is represented by an anolocyclic clone in the temperate zone of the European continent (including Belarus).

Since the material identified is small, and there is no published data on the fauna of myrmecophilous aphids in Belarus and neighboring countries, this study can be considered to be only a preliminary overview. Further study is planned for the future, and an expansion of the species list of myrmecophilous aphids in Belarus is to be expected.

\section{ORCID}

Artsiom M. Ostrovsky (iD 0000-0003-1729-9750

\section{References}

Addicott, J.F., 1978. Competition for mutualists: aphids and ants. Canadian Journal of Zoology 56, 2093-2096.

Aleeva, M.N., Babushkina, N.G., 1977. Entomofagi zlakovykh tlei [Entomophages of grass aphids]. 
In: Ivanov, O.A. (ed.), Effektivnost' khimizatsii sel'skogo khoziaistva v Sibiri. Sbornik nauchnykh trudov Sibirskogo otdeleniya VASKhNIL [Efficiency of agricultural chemicalization in Siberia. Collection of scientific papers of the Siberian Branch of V.I. Lenin All-Union Academy of Agricultural Sciences]. Siberian Research Institute of Agriculture and Chemicalization, Novosibirsk, USSR, 69-78. (In Russian).

Barannik, A.P., 1973. Pereponchatokrylye, vyvedennye iz tlei $v$ zelenykh, nasazhdeniiakh promyshlennykh gorodov Kuzbassa [Hymenoptera bred from aphids in green plantings of industrial cities of Kuzbass]. In: Barannik, A.P. (ed.), Priroda Kuzbassa [The nature of Kuzbass]. Novokuznetsk printing production plant, Novokuznetsk, USSR, 58-84. (In Russian).

Blackman, R.L., Eastop, V.F., 2006a. Aphids on the Herbaceous Plants and Shrubs. Vol. 1. Host Lists and Keys. Natural History Museum, Chichester, UK, $1024 \mathrm{p}$.

Blackman, R.L., Eastop, V.F., 2006b. Aphids on the Herbaceous Plants and Shrubs. Vol. 2. The Aphids. Natural History Museum, Chichester, UK, 1025-1439.

Blackman, R.L., Eastop, V.F., 2014. Aphids of the World's Plants: An Online Identification and Information Guide. Web page. URL: http://www. aphidsonworldsplants.info (accessed 22.02.21).

Bristow, C.M., 1984. Differential benefits from ant attendance to two species of homoptera on New York ironweed. Journal of Animal Ecology 53, 715726.

Davidyan, E.M., 2007. Sem. Aphidiidae Afidiidy [Family Aphidiidae]. In: Ler, P.A. (ed.), Opredelitel' nasekomykh Dal'nego Vostoka Rossii. T. IV. Setchatokryloobraznye, skorpionnitsy, pereponchatokrylye. Chast 5 [Key to the insects of Russian Far East. Vol. IV. Neuropteroidea, Mecoptera, Hymenoptera. Part 5]. Dal'nauka, Vladivostok, Russia, 192-255. (In Russian).

Depa, Ł., Mróz, E., 2012. Description of fundatrix morph of Stomaphis wojciechowskii Depa 2012 (Aphidoidea: Lachnidae). Genus 23 (3), 425-428.

Depa, Ł., Mróz, E., Szawaryn, K., 2012. Molecular identity of Stomaphis quercus (Hemiptera: Aphidoidea: Lachnidae) and description of a new species. European Journal of Entomology 109 (3), 435-444.
Dlusskii, G.M., 1967. Murav'i roda Formica [Ants of the genus Formica]. Nauka, Moscow, USSR, 235 p. (In Russian).

Filatova, I.T., 1970. Korovki (Coleóptera, Coccinellidae) Ob'-Eniseiskogo mezhdurech'ia [Ladybirds (Coleóptera, Coccinellidae) of the ObYenisei interfluve]. In: Cherepanov, A.I. (ed.), Fauna Sibiri [The fauna of Siberia]. Nauka, Novosibirsk, USSR, 88-100. (In Russian).

Heie, O.E., 1980. Aphidoidea (Hemiptera) of Fennoscandia and Denmark. I. General part. The families Mindaridae, Hormaphididae, Thelaxidae, Anoeciidae and Pemphigidae. Fauna Entomologica Scandinavica. Vol. 9. Scandinavian Science Press, Klapenborg, Denmark, 236 p.

Heie, O.E., 1982. Aphidoidea (Hemiptera) of Fennoscandia and Denmark. II. The family Drepanosiphidae. Fauna Entomologica Scandinavica. Vol. 11. Scandinavian Science Press, Klapenborg, Denmark, $176 \mathrm{p}$.

Heie, O.E., 1986. Aphidoidea (Hemiptera) of Fennoscandia and Denmark. III. The family Aphididae: subfamily Pterocommatinae et tribe Aphidini of subfamily Aphidinae. Fauna Entomologica Scandinavica. Vol. 17. E.J. Brill - Scandinavian Science Press, Leiden Copenhagen, Denmark, $314 \mathrm{p}$.

Heie, O.E., 1992. Aphidoidea (Hemiptera) of Fennoscandia and Denmark. IV. The family Aphididae: Part 1 of tribe Macrosiphini of subfamily Aphidinae. Fauna Entomologica Scandinavica. Vol. 25. Leiden, New York, København, Köln, $189 \mathrm{p}$.

Heie, O.E., 1994. Aphidoidea (Hemiptera) of Fennoscandia and Denmark. V. The family Aphididae: Part 2 of tribe Macrosiphini of subfamily Aphidinae. Fauna Entomologica Scandinavica. Vol. 28. Leiden, New York, Köln, 239 p.

Heie, O.E., 1995. Aphidoidea (Hemiptera) of Fennoscandia and Denmark. 6. The family Aphididae: Part 3 of tribe Macrosiphini of subfamily Aphidinae, and family Lachnidae. Fauna Entomologica Scandinavica. Vol. 31. Leiden, New York, Köln, 217 p.

Hodgson, J., Kaszyca-Taszakowska, N., Masłowski, A., Depa, Ł., 2019. The alate morph of Stomaphis wojciechowskii - first description and implications for species ecology. Bulletin of Insectology 72 (2), 233-240. 
Hölldobler, B., Wilson, E.O., 1990. The ants. The Belknap Press of Harvard University Press, Cambridge, Massachusetts, USA, $732 \mathrm{p}$.

Kadyrbekov, R.Kh., 2017. Tli (Hemiptera: Phylloxeroidea, Aphidoidea) Kazakhstana (Annotirovannyi spisok) [Aphids (Hemiptera: Phylloxeroidea, Aphidoidea) from Kazakhstan (Annotated list)]. Institute of Zoology of the Science Committee of the Ministry of Education and Science of the Republic of Kazakhstan, Almaty, Kazakhstan, 584 p. (In Russian).

Krotova, I.G., 1991. Khishchnye klopy semeistva Nabidae (Hemiptera), istrebliaiushchie tlei $v$ Priobskoi lesostepi [Predatory bugs of the family Nabidae (Hemiptera), exterminating aphids in the Priobskaya forest-steppe]. Zoologicheskii zhurnal [Zoological Journal] 70 (10), 59-68. (In Russian).

Krotova, I.G., 1992. Entomofagi zlakovykh tlei na posevakh zernovykh kul'tur $v$ severnoi lesostepi Priob'ia [Entomophages of cereal aphids on grain crops in the northern forest-steppe of the $\mathrm{Ob}$ region]. Biological Sciences $\mathrm{PhD}$ thesis abstract. Novosibirsk, 18 p. (In Russian).

Mamontova, V.A., 1973. Nastoiashchietli-Aphidoidea [The aphids - Aphidoidea]. In: Vasil'ev, V.P. (ed.), Vrediteli sel'skokhoziaistvennykh kul'tur i lesnykh nasazhdenii. T 1. Vrednye nematody, molliuski, chlenistonogie. Chast 1 [Pests of agricultural crops and forest stands. T. 1. Harmful nematodes, mollusks, arthropods. Part 1]. Urozhai, Kiev, USSR, 236-305. (In Russian).

Mordvilko, A.K., 1901. K biologii i morfologii tlei [On the biology and morphology of aphids]. Trudy Russkogo entomologicheskogo obshchestva [Proceedings of the Russian Entomological Society] 33, 418-475. (In Russian).

Mordvilko, A.K., 1936. Murav'i i tli [Ants and aphids]. Priroda [Nature] 4, 44-55. (In Russian).

Mróz, E., Depa, Ł., 2012. Molecular identification of atypical morph of Paracletus cimiciformis von Heyden, 1837 described as Forda rotunda Theobald, 1914 (Hemiptera: Aphidoidea: Eriosomatidae). Genus 23 (1), 17-24.

Nixon, G.E.J., 1951. The association of ants with aphids and coccids. Commonwealth Institute of Entomology, London, UK, $36 \mathrm{p}$.

Novgorodova, T.A., 2005. Dolevoi vklad chlenov mnogovidovoi assotsiatsii murav'ev $\vee$ potentsial chislennosti obshchikh simbiontov-tlei [The portion contribution of members of the multi-species association of ants to the population potential of common symbionts-aphids]. Doklady Akademii nauk [Reports of the Academy of Sciences] 401 (6), 848-849. (In Russian).

Offenberg, J., 2001. Balancing between mutualism and exploitation: the symbiotic interaction between Lasius ants and aphids. Behavioral Ecology and Sociobiology 49, 304-310.

Ostrovsky, A.M., 2021. Stomaphis wojciechowskii Depa, 2012 (Hemiptera: Aphididae: Lachninae) a new record of aphids in the fauna of Belarus. Kavkazskiy Entomologicheskiy bulleten [Caucasian Entomological Bulletin] 17 (1), 57-60. (In Russian). https://doi.org/10.23885/181433262021171-5760

Pälsson, K.J., 2002. Ants tending host-alternating aphids in different habitats: mutualism or exploitation? Department of ecology and crop production sciences $\mathbf{5 3}, \mathbf{1 - 1 2}$.

Panfilova, A.N., 1972. Entomofagi gorokhovoi tli v Kurganskoi oblasti [Entomophages of pea aphids in the Kurgan region]. Zashchita rastenii [Plant protection] 11, 29-30. (In Russian).

Pontin, A.J., 1960. Field experiments of colony foundation by Lasius niger (L.) and L. flavus (F.) (Hymenoptera, Formicidae). Insectes Sociaux 7, 227-230.

Remaudière, G., Remaudière, M., 1997. Catalogue of the word's Aphididae. INRA editions, Paris, France, $474 \mathrm{p}$.

Shaposhnikov, G.Kh., 1964. Podotriad Aphidinea - tli [Suborder Aphidinea - aphids]. In: Bei-Bienko, G. Ya. (ed.), Opredelitel' nasekomykh evropeiskoi chasti SSSR. T. I. Nizshie, drevnekrylye, s nepolnym prevrashcheniem [Key to the insects of the European part of the USSR. Vol. I. Lowers, ancients-winged, with incomplete transformations]. Nauka, Moscow - Leningrad, USSR, 489-616. (In Russian).

Tobias, V.I., Kiriyak, I.G., 1986. Sem. Aphidiidae Afidiidy [Family Aphidiidae]. In: Skarlato, O.A. (ed.), Opredelitel' nasekomykh evropeiskoi chasti SSSR. T. III. Pereponchatokrylye. Chast 5 [Key to the insects of the European part of the USSR. Vol. III. Hymenoptera. Part 5]. Nauka, Leningrad, USSR, 232-283. (In Russian). 